University of Nebraska - Lincoln

DigitalCommons@University of Nebraska - Lincoln

Faculty Publications - Chemistry Department Published Research - Department of Chemistry

2007

\title{
Corrosion Studies on the USS Arizona with Application to a Japanese Midget Submarine
}

\author{
Brent M. Wilson \\ University of Nebraska - Lincoln \\ Donald L. Johnson \\ University of Nebraska - Lincoln, johnsondonl@aol.com \\ Hans VanTilburg \\ NOAA National Marine Sanctuary \\ Matthew A. Russell \\ National Park Service, Submerged Resources Center \\ Larry E. Murphy \\ National Park Service, Submerged Resources Center
}

See next page for additional authors

Follow this and additional works at: https://digitalcommons.unl.edu/chemfacpub

Part of the Analytical Chemistry Commons, Medicinal-Pharmaceutical Chemistry Commons, and the Other Chemistry Commons

Wilson, Brent M.; Johnson, Donald L.; VanTilburg, Hans; Russell, Matthew A.; Murphy, Larry E.; Carr, James D.; De Angelis, Robert J.; and Conlin, David L., "Corrosion Studies on the USS Arizona with Application to a Japanese Midget Submarine" (2007). Faculty Publications -- Chemistry Department. 198.

https://digitalcommons.unl.edu/chemfacpub/198

This Article is brought to you for free and open access by the Published Research - Department of Chemistry at DigitalCommons@University of Nebraska - Lincoln. It has been accepted for inclusion in Faculty Publications -Chemistry Department by an authorized administrator of DigitalCommons@University of Nebraska - Lincoln. 


\section{Authors}

Brent M. Wilson, Donald L. Johnson, Hans VanTilburg, Matthew A. Russell, Larry E. Murphy, James D. Carr, Robert J. De Angelis, and David L. Conlin 


\title{
Corrosion Studies on the USS Arizona with Application to a Japanese Midget Submarine
}

\author{
Brent M. Wilson, Donald L. Johnson, Hans VanTilburg, Matthew A. Russell, Larry E. Murphy, \\ James D. Carr, Robert J. De Angelis, and David L. Conlin
}

1 Enhanced for the Web

This article appears on the JOM web

site (www.tms.org/JOMPT) in html

format and includes links to

additional on-line

resources.

The assessment of corrosion on the USS Arizona included the pioneering development of a minimum-impact costeffective technique to determine the corrosion rate of steel-hulled shipwrecks in seawater. The technique, with potential application worldwide, is illustrated in this paper with the application to a World War II Japanese midget submarine submerged in deep waters off the Oahu, Hawaii, coast.

\section{INTRODUCTION}

In the early morning hours of December 7, 1941, five Japanese class I fleet submarines launched five midget submarines ten miles off Pearl Harbor. The mission was to covertly slip into the harbor, wait until the attack by Japanese forces on Pearl Harbor began, then fire their torpedoes. Each vessel was $23.7 \mathrm{~m}$ long, had a beam of $1.8 \mathrm{~m}$, and a $1.4 \mathrm{~m}$ conning tower. Each submarine carried a crew of two and two torpedoes. At 3:57 a.m., Ensign R.C. McCloy, minesweeper Condor's officer of the deck, spotted something off his port bow and called over Quartermaster R.C. Uttrick. "That's a periscope sir, and there aren't meant to be any subs in this area." Ensign McCloy blinked a semaphore to USS Ward, "Sighted submerged submarine.
." Captain William W. Outerbridge, who earned his command only two days before, sounded general quarters, but secured at 4:35 a.m. having made no contact. At 5:50 a.m., Antares' skipper, Commander Lawrence C. Grannis, reported another sighting to Ward. By 6:40 a.m., Captain Outerbridge spotted a conning tower trailing Antares at the entrance to Pearl Harbor, closed to 45.7 $\mathrm{m}$, and fired a $10.2 \mathrm{~cm}$ round into the target. Although surviving documentation does not reveal that the site was the submarine sunk by Ward, evidence from the site, such as a shell hole at the starboard base of the conning tower (Figure 1) corresponds to the action report filed by Ward identifying the submarine as the first vessel sunk by the U.S. Navy in the Pacific war of World War II. ${ }^{1}$ The \#3, $10.2 \mathrm{~cm}$ gun from Ward, which fired the shot that sank the submarine, is now located on the Capitol Mall in St. Paul, Minnesota (Figure 2).

At 7:53 a.m., the Japanese initiated a surprise air attack against U.S. Forces stationed at Pearl Harbor and other military sites on Oahu, Hawaii. During the first wave, consisting of 183 fighters and torpedo bombers, Arizona became a total loss when a bomb penetrated the deck and sympathetically detonated its forward magazine. After the second wave of the attack consisting of 167 aircraft was over, 22 additional ships were damaged or totally lost with 2,403 killed in action, 1,173 of whom were lost on Arizona.

In August 2002, researchers in a Hawaiian Undersea Research Laboratory (HURL) submersible discovered this Japanese midget submarine approximately $4.83 \mathrm{~km}$ offshore from the entrance to Pearl Harbor, in 406.7 m of

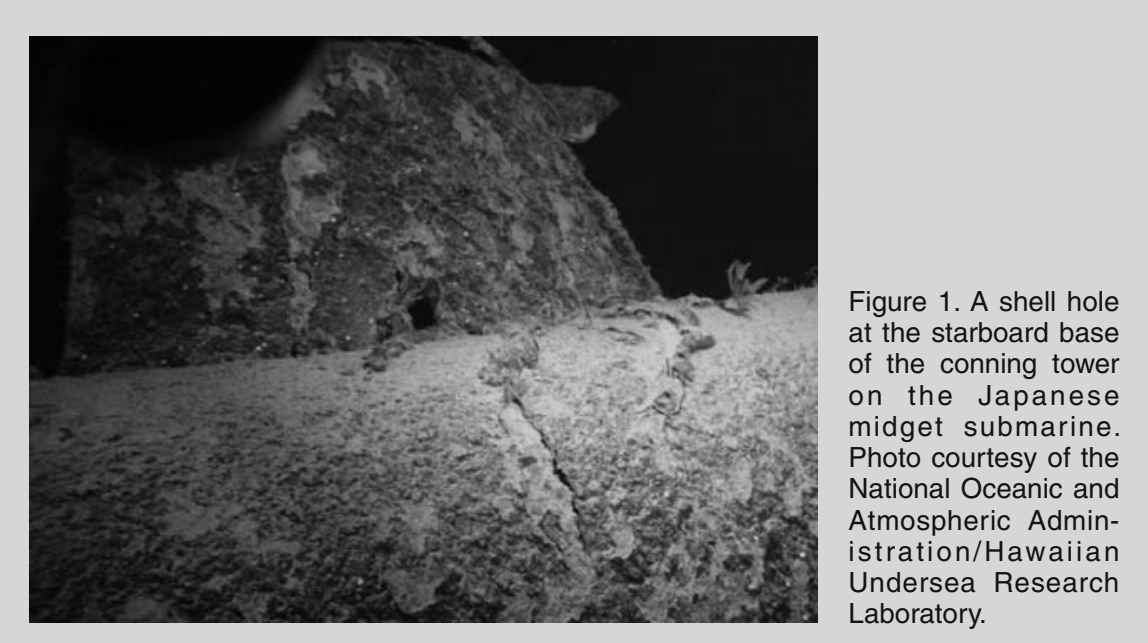

Over the last 40 years, there has been a discernible increase in the number of scholars who have focused their research on early industrial organizations, a field of study that has come to be known as Archaeotechnology. Archaeologists have conducted fieldwork geared to the study of ancient technologies in a cultural context and have drawn on the laboratory analyses developed by materials scientists as one portion of their interpretive program. Papers for this department are solicited and/or reviewed by Michael Notis, a professor and director of the Archaeometallurgy Laboratory (www.Lehigh.edu/ inarcmet) at Lehigh University. 




Figure 2. A number 3 gun, USS Ward, standing in front of the Minnesota Capitol, St. Paul, Minnesota. Robert Hall photo. water. In a later submersible descent, several small segments of marine concretion were recovered from the aft end of the midget sub by the robotic arm of HURL's Pisces submersible (Figure 3). These samples were analyzed in metallurgical and chemistry laboratories at the University of Nebraska-Lincoln, and $\mathrm{x}$-ray diffraction measurements were conducted at the Air Force Research Laboratory, Eglin Air Force Base, Florida. The purpose of this paper is to review Corrosion Equivalent Corrosion Rate (CECR) methodology, ${ }^{2}$ a minimum impact technique pioneered on Arizona, and its application to estimate the average corrosion rate of the external hull of the midget submarine. A second purpose is to present the results of X-ray diffraction studies on the concretion samples and to relate these results to physical and chemical properties of the submarine's concretion.

\section{TEST SITES}

\section{USS Arizona}

The Arizona remains submerged where it was sunk by Japanese forces on December 7, 1941. An estimated 1.9 million liters of fuel oil remain aboard, either in original bunkers or trapped beneath overheads of numerous undamaged compartments. Limited salvage operations on the vessel were terminated in 1942. A thorough archeological documentation of the wreck was initiated by the National Park Service and the U.S. Navy at the request of the USS Arizona Memorial superintendent in 1983. A detailed document including history, drawings, photographs, analysis, and recommendations for site management was published in $1990 .^{3}$ This initial document reported the earliest attempt to examine in-situ corrosion processes on a sunken steel ship. An interdisciplinary research program, the USS Arizona Preservation Project, began in 1999 to conduct a comprehensive study of corrosion, structural integrity, microbiology, sub-surface geology, and oceanography relevant to the in-situ site formation processes affecting the vessel. The data are providing critical inputs to a finite element model, which will constitute a composite research product to be used by managers in making future preservation decisions about the ship.

Several documents have been published since the Preservation Project's inception. The following references are specific to corrosion studies on the Arizona, and serve as the background for research done on the Japanese midget submarine that is the subject of this paper. References 4-7 contain information concerning the metallurgy, ${ }^{4}$ potential $/ \mathrm{pH}$ and metal coupon data, ${ }^{5,6}$ and minimum impact corrosion rate measurement technique., ${ }^{2,7}$

\section{Japanese Midget Submarine}

The midget submarine hull was fabricated from cold-rolled MS44, lowcarbon, basic open-hearth steel to an original wall thickness of $8 \mathrm{~mm} .{ }^{8}$ With no direct access to the submarine's hull, it was impossible to obtain metal samples that could directly reveal the extent of metal loss by laboratory metallographic methods. Ultrasound measurements were not attempted because experience with the heavily concreted Arizona hull has not provided conclusive data, ${ }^{6}$ and the method has not proven to be reliable with current technology. Electrochemical methods might be useful, but instantaneous data may not accurately reflect long-term corrosion. In addition, it would be expensive to monitor and service insitu instrumentation on site. As a result, the Japanese midget submarine discovered in 2002 appeared to be a suitable test site for the application of CECR methodology.,

\section{METAL/CONCRETION INTERACTIONS}

\section{USS Arizona}

$\mathrm{FeCO}_{3}$ (siderite), $\mathrm{CaCO}_{3}$ (aragonite), and $\mathrm{Fe}_{3} \mathrm{O}_{4}$ (magnetite) were the three major minerals present in Arizona concretion identified by a Siemens x-ray diffractometer. Iron contents varied from 18-65 wt.\%, with an average of approximately 50 wt.\% using environmental scanning-electron microscope (ESEM)

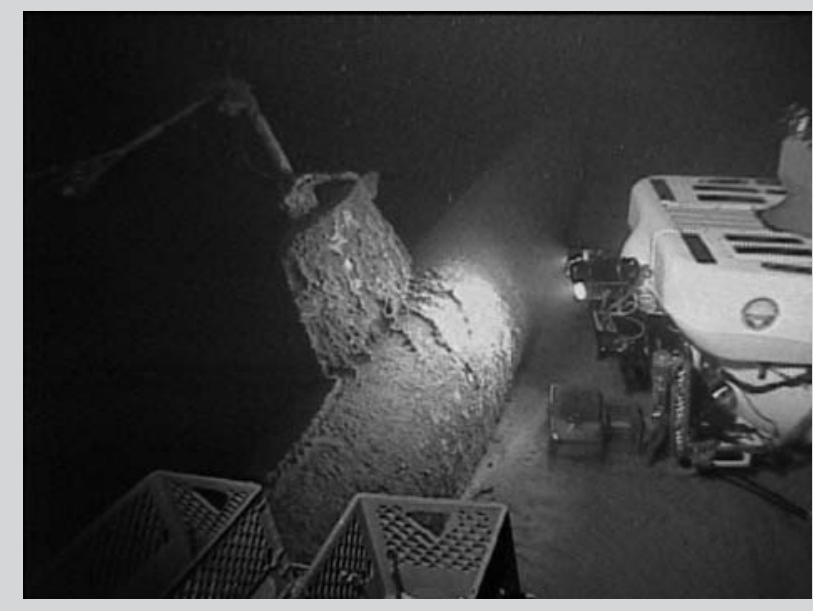

Figure 3. The aft end of the Japanese midget submarine during collection of concretion samples. Photo courtesy of the National Oceanic and Atmospheric Administration/ Hawaiian Undersea Research Laboratory. 
cross section scanning. ${ }^{7}$ Based on these observations, studies were initiated on Arizona to correlate iron content in the concretion with the average corrosion rate obtained from analysis of metal coupons removed from the hull in 2002. Results of this correlation are shown in Equation 1, where $\mathrm{i}_{\text {corr }}$ (CECR) is given. (All equations are shown in the table on page 17.) In this equation, $K=0.020$ for $i_{\text {corr }}$ in millimeters per year (mmpy); $\rho$ is concretion density $\left(\mathrm{g} / \mathrm{cm}^{3}\right)$; wt. $\% \mathrm{Fe}$ is weight percent iron; $d$ is concretion thickness $(\mathrm{cm})$; and $\mathrm{t}=61$ is exposure time (y).

\section{Japanese Midget Submarine}

As with Arizona concretion, a Siemens $\mathrm{x}$-ray diffractometer was used to scan the cross section of the midget submarine concretion samples from shipside to seaside at distances $0.03 \mathrm{~cm}, 0.05 \mathrm{~cm}, 0.08$ $\mathrm{cm}, 0.13 \mathrm{~cm}$, and $0.17 \mathrm{~cm}$ for siderite, goethite $(\mathrm{FeOOH})$, and magnetite. ${ }^{11}$ The diffractometer was situated on the calculated 2-theta peak for each mineral, and then scanned on either side from 0.5 to 1 degree so as to include the entire profile caused by line broadening. Figures 4, 5 , and 6 show the profiles for siderite, goethite, and magnetite, respectively, as a function of 2-theta angle and linear intensity (counts per second, Cps). As a general rule, intensity is approximately proportional to the concentration of a measured compound. Siderite occurs throughout the cross section, but appears to reach maximum concentration at the

Table I. Physical and Chemical Properties of Japanese Midget Submarine Concretion, and Calculated Concretion Equivalent Corrosion Rate (CECR)

\begin{tabular}{|c|c|c|c|c|c|}
\hline Sample & $\begin{array}{c}\mathrm{Fe} \\
\text { (wt.\%) }\end{array}$ & $\begin{array}{c}d \\
(\mathrm{~cm})\end{array}$ & $\begin{array}{l}\text { Density* } \\
\left(\mathrm{g} / \mathrm{cm}^{3}\right)\end{array}$ & $\begin{array}{l}\mathrm{H}_{2} \mathrm{O} \\
\text { (wt.\%) }\end{array}$ & $\begin{array}{c}\mathrm{i}_{\text {coor }}(\text { CECR })^{\star *} \\
(\mathrm{mmpy})\end{array}$ \\
\hline S1 & 52.7 & 0.335 & 2.017 & 25.5 & 0.012 \\
\hline S2 & 55.5 & 0.272 & 2.511 & 20.7 & 0.012 \\
\hline S3 & 61.8 & 0.523 & 1.619 & 50.3 & 0.017 \\
\hline S4 & 63.0 & 0.424 & 1.520 & 54.5 & 0.013 \\
\hline S5 & 58.3 & 0.447 & 1.809 & 39.6 & 0.015 \\
\hline S6 & 54.7 & 0.345 & 2.005 & 27.8 & 0.012 \\
\hline Average & 57.7 & 0.39 & 1.91 & 36.4 & 0.014 \\
\hline
\end{tabular}

* ASTM Designation D792-00

${ }^{* *}$ Equation 1

interior of the concretion toward seaside at $0.17 \mathrm{~cm}$. Goethite is highest in concentration toward shipside at $0.03 \mathrm{~cm}$, and lowest toward seaside at $0.17 \mathrm{~cm}$. Similarly, magnetite is highest in concentration toward shipside at $0.03-0.05$ $\mathrm{cm}$ and lowest toward seaside at 0.17 $\mathrm{cm}$. Aragonite does not appear in the $\mathrm{x}$-ray scans of the submarine concretion, although it does appear in Arizona concretion as mentioned previously.

Maximum siderite toward seaside (Figure 4) suggests that iron diffusion through the concretion is fast relative to siderite formation kinetics. The exact mechanism by which siderite forms is unknown, but it is probably related to iron exchange with calcium in calcium carbonate. ${ }^{12}$ North reported that the original aragonite skeletal material was converted into various iron compounds with siderite being the most common. Maximum goethite and magnetite toward

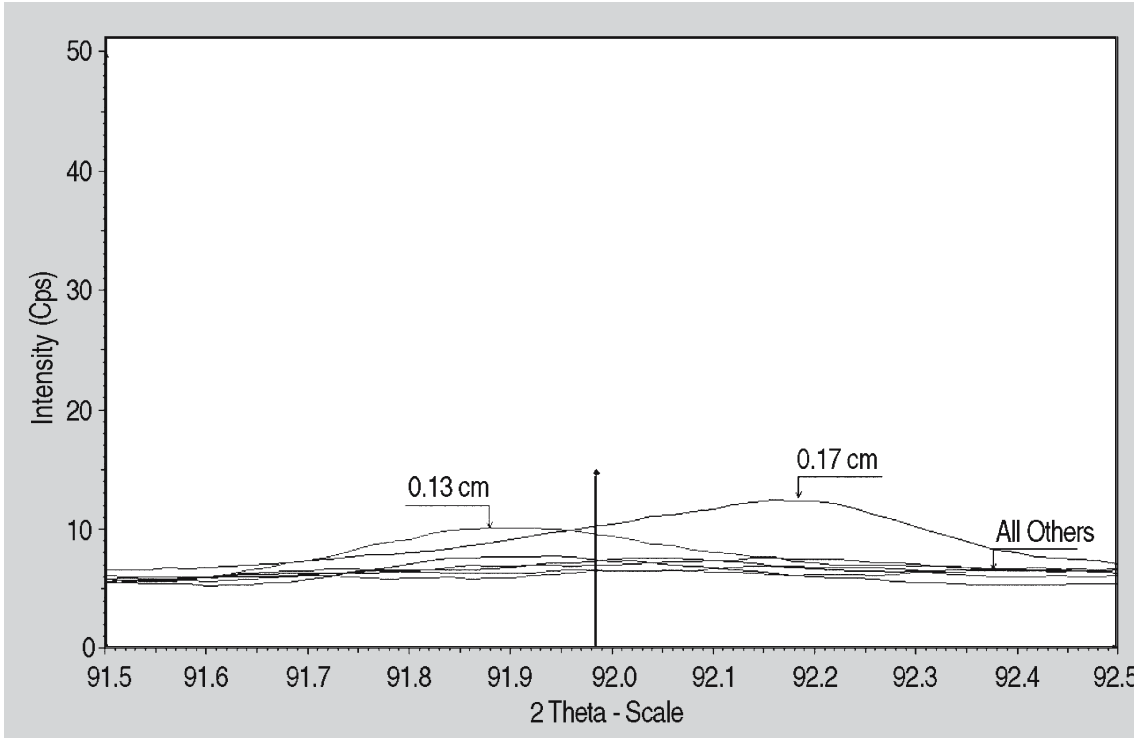

Figure 4. An x-ray diffraction intensity profile for siderite across the Japanese midget submarine concretion. shipside (Figures 5 and 6, respectively) suggests that oxygen diffusion is fast relative to iron oxide formation kinetics. The presence of goethite in the concretion rather than at the metal/concretion interface, as in the case of Arizona, may explain the higher iron content in the midget submarine concretion than in Arizona concretion. Although a chloridecontaining oxide, akaganeite, appears in Arizona scale, no chloride containing oxides appear in the midget submarine concretion. Other research indicates that akaganeite forms after the concretion is exposed to air ${ }^{13}$ which may explain the presence of this mineral in Arizona concretion, but it does not explain its absence in the midget submarine concretion.

\section{CORROSION}

\section{Concretion Equivalent Corrosion Rate}

From a collection of midget submarine concretion samples, the six largest were designated as samples S1, S2, S3, $\mathrm{S} 4, \mathrm{~S} 5$, and S6. To begin, concretion density was measured, then thickness and water content were determined. Last, the samples were ground to a fine powder and delivered to the Department of Chemistry analytical laboratory at the University of Nebraska-Lincoln for iron analysis using wet chemical methods. The data, including CECR data from Equation 1, are given in Table I.

The CECR predicts an average corrosion rate of $0.014 \mathrm{mmpy}$, corresponding to a total hull loss of $0.9 \mathrm{~mm}$, with approximately $7.1 \mathrm{~mm}$ of metal remaining. For comparison, Arizona concretion contained significantly lower iron, varying between $22-48$ wt.\%, greater concretion thickness, averaging $1.8 \mathrm{~cm}$, 
greater concretion density, varying from $1.9-2.5 \mathrm{~g} / \mathrm{cm}^{3}$, and lower water retention at approximately $14 \mathrm{wt} . \%$.

\section{Corrosion Mechanism—Limiting Current}

In sea water, oxygen reduction at cathodic sites is typically the driving force for the corrosion process. Assuming oxygen reduction is the only cathodic reaction, the limiting corrosion rate is calculated using Fick's First Law according to Equation 2, where: $i_{\text {corr }}(l)$ is the limiting corrosion rate (mpy), $\mathrm{J}=\mathrm{KDC} /$ $\mathrm{d}$ is the oxygen flux through concretion $\left(\mathrm{g} \mathrm{O}_{2} / \mathrm{cm}^{2} / \mathrm{s}\right), \mathrm{K}=0.012$ for $\mathrm{i}_{\text {corr }}$ in mmpy,

Equations

$$
\begin{gathered}
i_{\text {corr }}(C E C R)=\frac{K \rho d(w t . \% F e)}{t} \\
i_{\text {corr }}\left(O_{2} \text { reduction }\right)=i_{\text {corr }}(I)=\frac{K D C}{d} n F \quad[\mathrm{mmpy}] \\
i_{\text {corr }}\left(O_{2} \text { reduction }\right)=\frac{(0.012)\left(1.72 \times 10^{-5}\right)(4.42)}{0.39}(0.125)(96,500) \cong 1.1 \mathrm{mpy}[0.028 \mathrm{mmpy}]
\end{gathered}
$$

$\mathrm{D}$ is the diffusion coefficient for $\mathrm{O}_{2}$ in water $\left(\mathrm{cm}^{2} / \mathrm{s}\right), \mathrm{d}$ is concretion thickness (cm), $\mathrm{n}$ is the number of equivalent electrons transferred per gram atomic

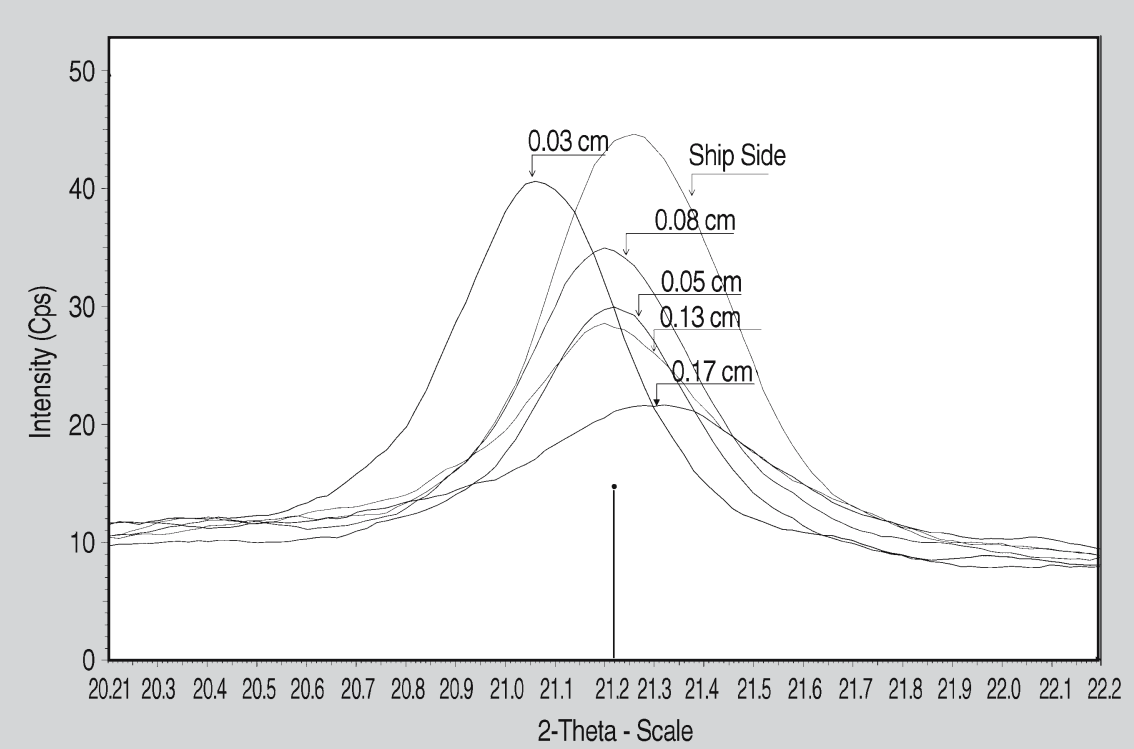

Figure 5. X-ray diffraction intensity profiles for goethite across the Japanese midget submarine concretion.

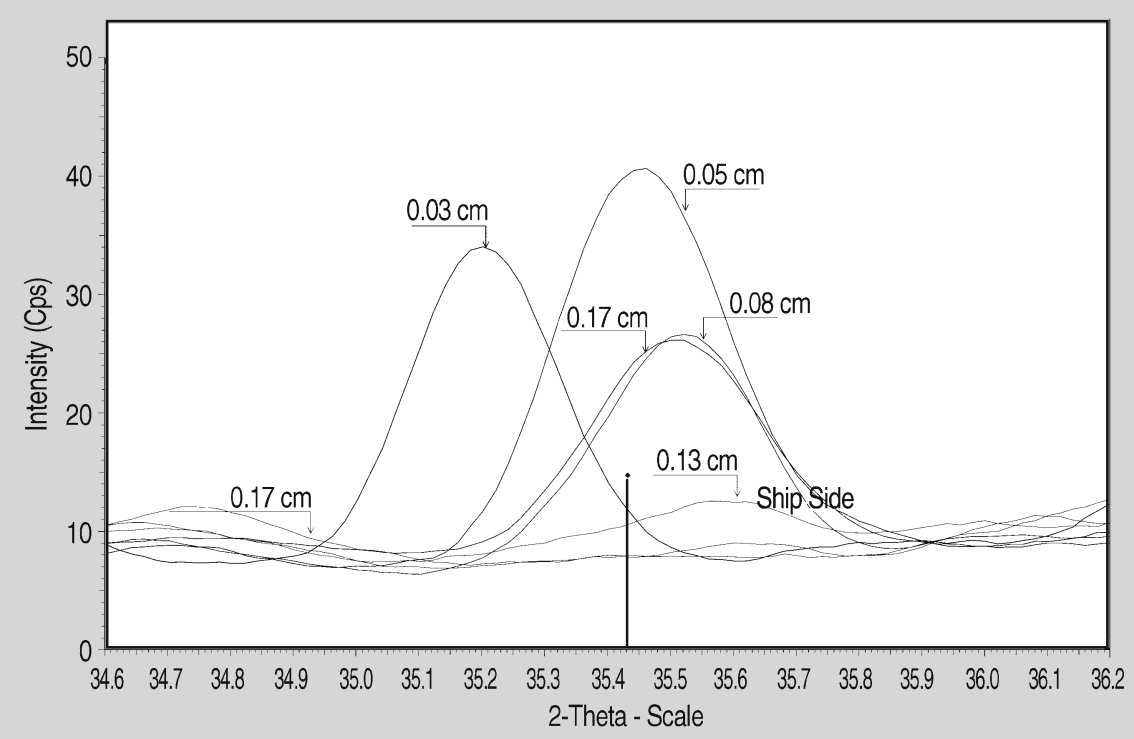

Figure 6. X-ray diffraction intensity profiles for magnetite across the Japanese midget submarine concretion. The double peaks at $0.17 \mathrm{~cm}$ result from heterogeneity in the concretion. weight, $\mathrm{F}$ is the Faraday constant $(\mathrm{A} \cdot \mathrm{s} /$ $\mathrm{e}^{-}$), and $\mathrm{C}$ is the oxygen concentration at the concretion/seaside interface, or gradient across the concretion assuming $\mathrm{C}$ at the concretion/metal interface $\cong 0$ $(\mathrm{mg} / \mathrm{L})$.

The diffusion coefficient for oxygen in water, $\mathrm{D}$, is estimated at $8.8^{\circ} \mathrm{C}$ using $\mathrm{D}_{25} \cdot\left(\mathrm{T} / \mathrm{T}_{25}\right)\left(\mu_{25} / \mu\right)$, where $\mathrm{D}_{25}$ is the diffusion coefficient for oxygen at $25^{\circ} \mathrm{C}, \mu$ is the viscosity of water, and $\mathrm{T}$ is absolute temperature. At $8.8^{\circ} \mathrm{C}, \mathrm{D}$ equals $1.72 \times$ $10^{-5} \mathrm{~cm}^{2} / \mathrm{s}^{14}$ and $\mathrm{C}(\mathrm{sat})=47.24 \%$. Based on a mean temperature of $8.8^{\circ} \mathrm{C}$ at a water depth of $406.7 \mathrm{~m}$,and a mean salinity of $34.1, \mathrm{C}$ (sat) converts to $\mathrm{C}=$ $4.42 \mathrm{mg} / \mathrm{L}$, with a standard deviation of $0.9 \mathrm{mg} / \mathrm{L} .{ }^{15}$ From Table I, d (average) $=$ $0.39 \mathrm{~cm}, \mathrm{n}=2 / 16=0.125$, and $\mathrm{F}=96,500$ $\mathrm{A} \cdot \mathrm{s} / \mathrm{e}^{-}$. When these values are substituted into Equation 2, Equation 3 results.

Comparison to the CECR indicates that $\mathrm{i}_{\text {corr }}\left(\mathrm{O}_{2}\right.$ reduction $)$ is greater than $\mathrm{i}_{\text {corr }}$ (CECR) by approximately $0.014 \mathrm{mmpy}$. This difference may be caused by ratelimited mineral formation kinetics in the concretion. It is of interest to note that the corrosion rate from coupon measurements on Arizona is greater than that calculated from Equation 2, the opposite of that observed on the midget submarine. ${ }^{6}$ The authors suggest that hydrogen discharge, stimulated by microbial activity, supports corrosion on Arizona, but is less of a factor on the midget submarine. ${ }^{16}$

\section{CONCLUSION}

Based on CECR, the average corrosion rate of the Japanese midget submarine hull, submerged in $406.7 \mathrm{~m}$ of sea water, is estimated to be 0.014 mmpy, corresponding to a 61 year loss of approximately $11 \%$ of its original hull thickness. Iron in the midget submarine concretion appears in the form of the minerals goethite, magnetite, and sider- 
ite. Formation kinetics of these minerals may be rate limiting. Unlike Arizona concretion, aragonite was not detected. High water retention, combined with low concretion thickness, may explain the high oxygen availability at the metal/concretion interface. To lend support to these conclusions, two avenues of approach are being pursued. The first is to search for other marine sites where it is feasible to collect concretion samples, and measure on-site environmental parameters: oxygen saturation (\%), temperature, salinity, and $\mathrm{pH}$. The second approach is to conduct an in-depth study of concretion morphology with corresponding experimental measurement of iron and oxygen diffusivity, and kinetics of formation of iron-bearing minerals in the concretion.

While water depth reflects environmental properties, incorporation of these environmental properties directly into Fick's First Law for limiting current can be used to better understand the corrosion process.

\section{ACKNOWLEDGEMENTS}

The USS Arizona Preservation Project is funded by the Department of Defense, Legacy Resource Management Fund; National Park Service System Wide Archeological Inventory Program; National Park Service Submerged Resources Center; USS Arizona Memorial and Arizona Memorial Museum
Association. Additional thanks to Terry Kerby, Hawaiian Undersea Research Laboratory, University of Hawaii; National Oceanic and Atmospheric Administration(NOAA)/National Ocean Service Pacific Islands Region; Dan Basta, National Marine Sanctuary Program; Northwest Hawaiian Islands National Marine Sanctuary; NOAA Maritime Heritage Program and the University of Nebraska Foundation. The authors also thank Dr. John Makinson (Rail Sciences, Inc.); Inspection Technologies, Inc.; Titan Maritime Industries, Inc.; and especially Doug Lentz for his continuing support. This research is dedicated to the memory of Dr. William N. Weins.

\section{References}

1. Sid Moody with additional text by Hugh A. Mulligan, Edited by Norm Goldstein, photo research by Susan Brady, Pearl Harbor, 50th Anniversary Special Addition (Emeryville, CA: The Associated Press, Longmeadow Press, 1991)

2. Matthew A. Russell et al., "A Minimum-Impact Method for Measuring Corrosion Rate of Steel-Hulled Shipwrecks in Seawater," The International Journal of Nautical Archeology, 35.2 (September 2006), pp. 310-318.

3. D.J. Lenihan, editor, Submerged Resources StudyUSS Arizona, Southwest Cultural Resources Center Professional Papers, No 23, 2nd Edition (Santa Fe, NM: National Park Service, 1990).

4. D.L. Johnson et al., "Metallographic Studies on USS Arizona," Microstructural Science, 27 (2000), pp. 85-91.

5. J.D. Makinson et al., "In Situ Corrosion Studies on the Battleship USS Arizona," Materials Performance, 41 (10) (2002), pp. 56-60.
6. Donald L. Johnson et al., "Corrosion of Steel Shipwrecks in Marine Environment, USS Arizona - PART I," Materials Performance, 45 (10) (2006), pp. 40-44.

7. Donald L. Johnson et al., "Corrosion of Steel Shipwrecks in Marine Environment, USS Arizona - Part II," Materials Performance, 45 (10), pp. 54-57. 8. Reports of the U.S. Naval Technical Mission to Japan 1945-1946, Microfilm Publication 2 (Washington, D.C.: Operations Archives, U.S. Naval History Division, May 1974).

9. Robert De Angelis, X-ray Diffraction and Environmental Scanning Electron Microscope Investigation of Concretion from the USS Arizona Report (Eglin Air Force Base, FL: Air Force Research Laboratory, 27 September 2002).

10. D.L. Johnson et al., Metallurgical and Corrosion Study of Battleship USS Arizona, USS Arizona Memorial, Pearl Harbor (Santa Fe, NM: Report to Submerged Resources Center, 31 May 2003).

11. X-ray Presentation (Eglin Air Force Base, FL: Air Force Research Laboratory, 21 January 2005).

12. Neil A. North, "Formation of Coral Concretion on Marine Iron," The International Journal of Nautical Archeology and Underwater Exploration, 5.3 (1976), pp. 253-258.

13. Desmond Cook, Old Dominion University, personal communication (12 March 2007)

14. Robert H. Perry and Cecil H. Chilton, editors, Chemical Engineers' Handbook, 5th Edition (New York, NY: McGraw-Hill Book Company, 1973), pp. 3224, 3-212, 3-213.

15. David Murphy, Sea-Bird Electronics, Bellevue, WA personal communication (2006)

16. M. Schmacher, editor, Seawater Corrosion Handbook (Park Ridge, NJ: Noyes Data Corporation, 1979), pp. 367-387.

Brent M. Wilson, Donald L. Johnson, and James D. Carr are with the University of Nebraska-Lincoln; Hans VanTilburg is with NOAA National Marine Sanctuary; Matthew A. Russell, Larry E. Murphy, and David L. Conlin are with the National Park Service, Submerged Resources Center; and Robert J. De Angelis is with the University of Florida, Graduate Engineering and Research Center, Shalimar, Florida. Prof. Johnson can be reached at (623) 975-1657; e-mail johnsondonl@aol.com. 